\title{
PPM PENINGKATAN PRODUKTIFITAS SEMANGGI SUROBOYO DI KELURAHAN SEMEMI, KECAMATAN BENOWO SURABAYA
}

\author{
Faisol Humaidi ${ }^{1}$, Dwiyana Anela Kurniasari, ${ }^{2}$, Adelia Putriani ${ }^{3}$, Ananda Istiqomah $\mathbf{N}^{4}$ \\ ${ }^{1,2,3,4}$ Universitas Wijaya Putra
}

faisolhumaidi@uwp.ac.id,dwiyanaanela@uwp.ac.id,putrianiadellia@gmail.com,putrianiadellia@gmail.com, istiqomahananda410@gmail.com

\begin{abstract}
Abstrak
Mitra dalam Program Pemberdayaan Masyarakat ini adalah Bapak Lodji yang mengeluti usaha budidaya Semanggi di Dusun Kendung Kelurahan Sememi Kecamatan Benowo Surabaya. Permasalahan-permasalahan yang dihadapi mitra, antara lain; 1). Rendahnya Produksi daun Semanggi; 2). Kurangnya sanitasi lahan budidaya; 3). Kurangnya suplai air irigasi pertanaman Semanggi di musim kemarau; 4). Menurunya luasan lahan pertanaman Semanggi; 5). Menurunnya kesuburan lahan pertanaman Semanggi; 6). Terbatasnya pemasaran daun Semanggi yang hanya untuk pemasok pedagang pecel Semanggi; 7). Sistem pemasaran bersifat tradisional; Sedangkan tujuan dari kegiatan PPM ini adalah menjadikan kelompok tani Semanggi lebih produktif dalam budidaya daun Semanggi. Metode yang dilaksanakan antara lain; Penggunaan paket teknologi budidaya Semanggi dengan pupuk organik yang memadai dengan menggunakan biofertiliser; Perlunya perbaikan saluran drainasi dan suplai air budidaya Semanggi terpenuhi. Hasil kegiatan PPM ini yaitu: Produksi daun Semanggi terjamin pasokannya ke pedagang pecel Semanggi; Suplay air dan biofertilizer untuk tanaman Semanggi dapat terpenuhi di musim kemarau dan produksi meningkat sebesar 67\% serta produksi daun Semanggi menjadi berkesinambungan; Tingkat kesuburan tanah meningkat ; Adanya peningkatan pendapatan petani Semanggi Suroboyo sebesar $65 \%$. Adapun luaran adalah prosiding ilmiah terakreditasi dan HKI.
\end{abstract}

Kata Kunci : PPM, Semanggi, biofertilizer,

\section{PENDAHULUAN}

Semanggi air (Marsilea crenata $\quad$ L.) merupakan salah satu tumbuhan air yang telah banyak dimanfaatkan oleh masyarakat sebagai bahan pangan. Seperti "Semanggi Suroboyo" makanan yang menerapkan konsep pecel, yakni makanan khas orang Jawa yang merupakan paduan sayursayuran dan saus kacang berbumbu. Namun, memiliki bahan dasar dan saus khas yang membedakannya dengan jenis pecel lainnya. Kekhasan bahan dan rasanya menjadikan "Semanggi Suroboyo" layak disebut sebagai pecel Surabaya. Sesuai dengan namanya, bahan baku kuliner yang satu ini adalah daun Semanggi air. Semanggi adalah jenis tanaman yang termasuk kelompok paku air. Tanaman ini memiliki bentuk fisik yang khas karena susunan daunnya mirip payung yang terdiri atas empat anak daun dengan posisi berhadapan (bisnissurabaya.com. 2019).

Semanggi memiliki kandungan gizi air sebanyak 89.02 persen, abu 2.7 persen, protein 4.35 persen, lemak 0.27 persen, serat kasar 2.28 persen, 
dan karbohidrat sebesar 1.38 persen. Selain itu, kandungan senyawa saponin, zat samak dan minyak atsiri baik untuk mengobati berbagai penyakit di dalam tubuh. Seperti ampuh untuk mengatasi infeksi saluran kencing, mengobati terlambat datang bulan, anti hipertensi serta mencegah lelah dan lesu (Gita, 2019). Semanggi merupakan makanan khas arek-arek Suroboyo. Kuliner berbahan dasar dedaunan ini kemudian disiram bumbu khasnya, ditambah kerupuk puli sebagai pelengkap. Makanan ringan ini penyajiannya diatas daun pisang berbentuk segitiga ini diminati warga Surabaya (Sugijo, Tjitrawardani, 1998).

Sebenarnya, makanan khas ini berawal dari banyaknya semak Semanggi di pojok kampung Surabaya yang dipenuhi rawa. Warga kemudian berinisiatif membuatnya menjadi olahan makanan. Tetapi, tumbuhan Semanggi ini hanya tumbuh di beberapa tempat saja. Seperti, di Kecamatan Benowo, khususnya Kampung Kendung, Kelurahan Sememi. "Mayoritas warga tersebut adalah penjual Semanggi. Ada yang menanam semanggi sendiri. Tetapi, ada pula yang membeli dari petani semanggi Jadi, tak heran jika kampung tersebut dijuluki Kampung Semanggi Suroboyo.

Keberadaan petani-petani semanggi kelurahan Sememi pada tahun 2021 sebanyak 13 orang dengan kepemilikan lahan sebagian besar $(60 \%)$ bergeser ke sewa lahan dan sisanya milik pribadi dengan luas rata-rata berkisar $200 \mathrm{~m} 2$. Produktifitas daun Semanggi mensuplai sekitar 300 pedagang pecel semanggi yang sebagian besar warga kendung kelurahan Sememi, Kecamatan Benowo Surabaya. Dengan perkembangan globalisasi dan luasan lahan budidaya semanggi, pada tahun 2021 terjadi banyak penurunan produktifitas lahan serta permasalahan klasik seperti berkurangnya lahan akibat percepatan pembangunn pemukiman penduduk.

Masyarakat mulai kesulitan mencari menu tersebut, dan keberadaannya yang tanpa inovasi semakin mengaburkan keberadaannya di tengah masyarakat, terlebih generasi muda. Sangat disayangkan apabila menu semanggi ini harus hilang dari warisan kekayaan kuliner tradisional. Namun juga harus ada strategi yang tepat agar menu Semanggi tetap hidup di masyarakat (CA Tresyanto, 2016).
Dari 300 penjual produk pecel Semanggi Suroboyo, sehari bisa menghabiskan daun semanggi sebanyak $240 \mathrm{~kg}$ sampai dengan $300 \mathrm{~kg}$ daun semanggi atau setiap pedagang Semanggi Suroboyo atau menghabiskan daun semanggi sebanyak 800 gram sampai dengan $1 \mathrm{~kg}$ per hari. Sedangkan dari sektor hulu berupa produksi daun Semanggi per hari belum bisa mencukupi kebutuhan suplai daun semanggi yang setiap hari selalu mengalami peningkatan permintaan dari pedagang pecel Semanggi Suroboyo. Produktifitas daun semanggi dari 13 pembudidaya setiap harinya belum bisa dipanen secara serempak karena karakter dari tanaman Semanggi merupakan tanaman merambat di air sangat tergantung dari kebutuhan air yang bersih dan pemupukan yang berimbang. Di musim kemarau produksi daun Semanggi menjadi merosot dikarenakan masalah kebutuhan air yang belum tercukupi. Dari problematika inilah team PPM dari Fakultas Pertanian Universitas Wijaya Putra Surabaya berkontribusi membantu penanganan kekurangan pasokan daun semanggi dengan kelompok petani budidaya Semanggi Suroboyo dengan paket teknologi dengan peningkatan produksi berbasis agroekosistem berkelanjutan.

\section{METODE}

Dalam rangka melaksanakan solusi dan mencapai target luaran diatas, berikut metode pelaksanaan kegiatan yang menjelaskan tahapan atau langkahlangkah dalam melaksanakan solusi yang ditawarkan untuk mengatasi permasalahan sebagai berikut:

1. Koordinasi dengan mitra petani Semanggi Suroboyo

2. Menentukan prioritas pelaksanaan program

a. Pembuatan tandon air untuk suplai pengairan tanaman Semanggi

b. Pembuatan biofertilizer dalam peningkatan produktifitas tanaman Semanggi

c. Perbaikan saluran drainase

3. Demplot budidaya semanggi dengan konsep semi organik. 
Pelaksanaan Program PPM Semanggi Suroboyo dimulai bulan Juli 2021 sampai dengan akhir Oktober 2021.

Prioritas solusi dan pelakanaan program PPM Semanggi Suroboyo juga dibantu dari tingkat RT dan mitra dalam hal ini Bapak Lodji mempersiapkan lahan/tempat pelaksanaan program PPM. Juga pelaksanaan PPM ini berkolaborasi dengan kegiatan KKN mahasiswa Universitas Wijaya Putra yang bertempat di area mitra bapak Loji RT 07, Kelurahan Kendung Kecamatan Benowo Surabaya.

Partisipasi mitra dalam kegiatan PPM ini adalah menyediakan lahan tempat demplot, tenaga kerja dalam membantu pembuatan tendon air biofertilizer serta pembuatan sumur yang dibantu pihak CsR Astra.

Monitoring dan evaluasi kegiatan dilaksanakan setiap 2 minggu sekali dengan melibatkan 2 mahasiswa prodi Agribisnis Universitas Wijaya Putra Surabaya. Pelaksanaan monitoring berakhir pada bulan oktober 2021.

\section{HASIL DAN PEMBAHASAN}

Pelaksanaan awal peningkatan produktifitas Semanggi Suroboyo dengan berkoordinasi, berdiskusi dan implementasi program budidaya semanggi suroboyo yang juga difasilitasi pihak CsR Astra. Model pendekatan program dengan menggunakan tahapan-tahapan sebagai berikut:

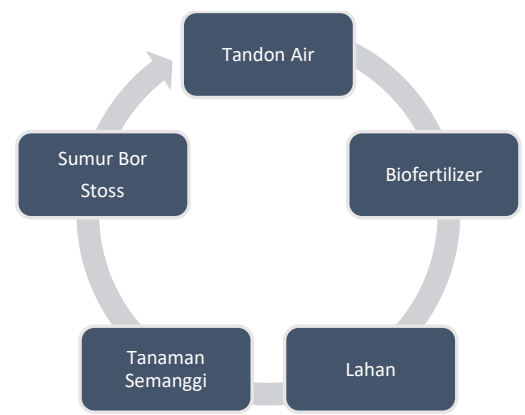

Pemasangan tandon air ditempatkan di lahan Semanggi milik mitra Bapak Lodji. Tandon air terpasang setelah suplai air sudah terpenuhi dengan adanya sumur. Tandon air yang sudah terisi diberi biofertilizer di fermentasi selama 2-3 hari. Setelah itu diaplikasikan ke tanaman semanggi dengan penambahan pupuk NPK. Hasil Pertumbuhan semanggi dengan menggunakan metode semi organik dengan pengunaan biofertilizer dan sedikit pupuk NPK dengan harapan dapat meningkatkan produktifitas tanaman Semanggi.

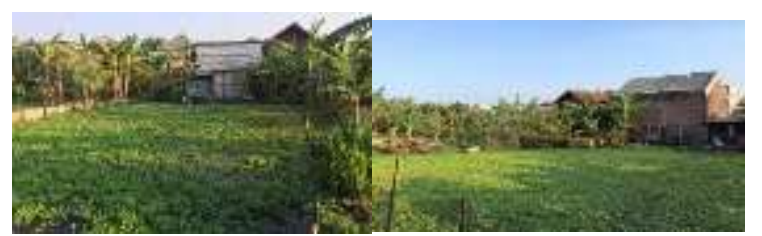

Gambar 1.Tanaman Semanggi tidak dipupuk (kiri) dan tanaman semanggi aplikasi biofertilizer (kanan).

Produktifitas daun semanggi dalam kebiasaan petani setiap 10 hari sekali 2 kali panen, dengan menggunakan biofertilizer dan pupuk NPK 15-1515 dengan perbandingan 1-1 didapatkan hasil sebagai berikut

Tabel 1. Periodisasi panenan daun Semanggi dengan penggunaan pupuk Biofertilizer + NPK 15-15-15 .per 10 hari sekali. (Kondisi daun kering)

\begin{tabular}{|l|l|l|l|l|l|}
\hline $\begin{array}{l}\mathrm{N} \\
\text { o }\end{array}$ & Perlakuan & $\begin{array}{l}\text { Period } \\
\text { isasi } \\
\text { Panen/ } \\
10 \text { hari }\end{array}$ & $\begin{array}{l}\text { Prod } \\
\text { uksi } \\
(\mathrm{Kg}) / \\
10 \\
\text { hari }\end{array}$ & $\begin{array}{l}\text { Prod } \\
\text { uksi } \\
\text { dala } \\
\mathrm{m} \mathrm{1} \\
\text { bulan } \\
(\mathrm{kg})\end{array}$ & $\begin{array}{l}\text { Pendap } \\
\text { atan } \\
\text { Kotor } \\
(\mathrm{Rp})\end{array}$ \\
\hline 1 & $\begin{array}{c}\text { Tanpa } \\
\text { Aplikasi } \\
\text { Biofertilize } \\
\text { r+NPK }\end{array}$ & 2 & 20 & 60 & $\begin{array}{c}1.800 .0 \\
00\end{array}$ \\
\hline 2 & $\begin{array}{c}\text { Aplikasi } \\
\text { Biofertilize } \\
\text { r+NPK }\end{array}$ & 3 & 30 & 90 & $\begin{array}{c}2.700 .0 \\
00\end{array}$ \\
\hline
\end{tabular}

Perlakuan dengan menggunkan biofertilizer juga mereduksi limbah air dari rumah tangga dan saluran pembuangan sehingga serapan pupuk NPK menjadi 
maksimal. Hal ini terbukti dengan peningkatan panenan 3 kali dalam 10 hari.

Daun Semanggi yang sudah dipanen selanjutnya dijemur/dikering anginkan. Setelah kering dapat dijual dengan harga per $1 \mathrm{~kg}$ kering sebesar Rp.30.000.- Rata-rata petani Semanggi Suroboyo menjual daun semanggi kering dengan kisaran 20 $\mathrm{kg}$ per 10 hari. Jika diambil rata-rata penjualan per 10 hari maka pendapatan petani semanggi sebesar Rp.600.000.-. Per bulan didapatkan hasil penjualan Rp. 1.800.000.-. Penggunaan biofertilizer dan NPK dapat meningkatkan periodisasi panenan menjadi 3 kali sehingga dapat meningkatkan pendapatan kelompok tani Semanggi Suroboyo selama 1 bulan sebesar Rp.2.700.000.-.Pendapatan tersebut belum dipotong dengan biaya produksi seperti sarana produksi seperti pupuk, insektisida organik dan tenaga kerja. Dikarenakan luasan tanaman Semanggi rata-rata kecil maka variabel tenaga kerja tidak dihitung.

Tabel 2. Asumsi Pendapatan Petani Semanggi Suroboyo dengan Aplikasi Biofertilizer+NPK (Periode 1 Bulan)

\begin{tabular}{|l|l|l|l|l|}
\hline $\begin{array}{l}\text { N } \\
\text { o }\end{array}$ & Perlakuan & $\begin{array}{l}\text { Penerima } \\
\text { an }\end{array}$ & $\begin{array}{l}\text { Pengeluar } \\
\text { an }\end{array}$ & $\begin{array}{l}\text { Hasil } \\
\text { Bersih } \\
\text { (Rp) }\end{array}$ \\
\hline 1 & $\begin{array}{l}\text { Tanpa Aplikasi } \\
\text { Biofertilizer+N } \\
\text { PK }\end{array}$ & $\begin{array}{l}1.800 .00 \\
0\end{array}$ & 150.000 & $\begin{array}{l}1.650 .0 \\
00\end{array}$ \\
\hline 2 & $\begin{array}{l}\text { Aplikasi } \\
\text { Biofertilizer+N } \\
\text { PK }\end{array}$ & $\begin{array}{l}2.700 .00 \\
0\end{array}$ & 150.000 & $\begin{array}{l}2.550 .0 \\
00\end{array}$ \\
\hline
\end{tabular}

Dari tabel 2 diatas nampak dengan perlakuan aplikasi biofertilizer+NPK dapat meningkatkan produksi daun semanggi sebesar $67 \%$ serta dapat meningkatkan pendapatan petani Semanggi Suroboyo sebesar $65 \%$.

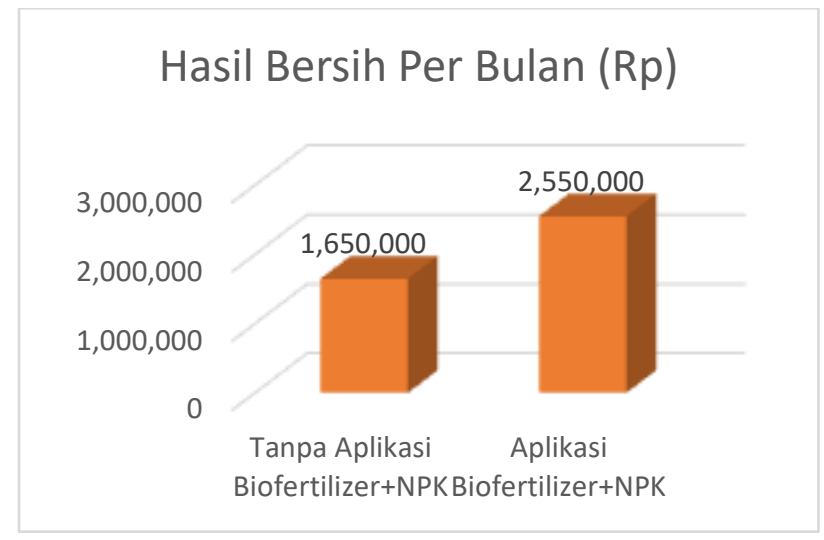

Gambar 2. Grafik peningkatan pendapatan petani semanggi suroboyo dalam kurun waktu 1 bulan

Langkah selanjutnya dalam pemberdayaan petani Semanggi Suroboyo dengan inovasi membuat pupuk biofertilizer dengan dibimbing oleh tim dari Fakultas Pertanian Universitas Wijaya Putra. Pembuatan awal dilaksanakan di laboratorium Biologi Fakultas Pertanian Universitas Wijaya Putra dengan dibantu oleh mahasiswa fakultas Pertanian Universitas Wijaya Putra.

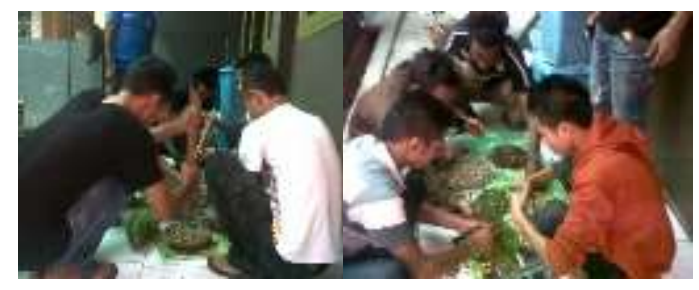

Gambar 2. Proses pembuatan pupuk biofertilizer.

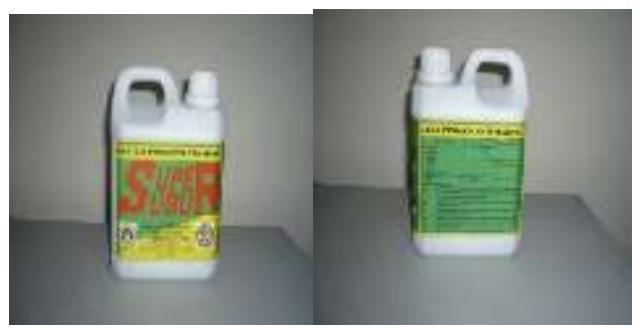

Gambar3. Propotype pupuk biofertilizer kerjasama petani Semanggi dengan team Fakultas Pertanian Universitas Wijaya Putra. 
Pembuatan biofertilizer menggunakan limbah rumah tangga seperti sisa sayuran, nasi, dan limbah organik lainnya yang telah difermentasi menggunakan yeast. Waktu fermentasi sekitar 2 minggu menjadi cairan fertilizer yang siap dipackaging seperti gambar 3 diatas. Dalam kurun waktu ke depan produk pupuk cair/biofertizer disamping untuk petani semanggi seindiri juga dijual dengan harga Rp.20.000.- per botol.

\section{KESIMPULAN}

Pelaksanaan PPM di kampung Semanggi Suroboyo di dusun Kendung, Kelurahan Sememi, Kecamatan Benowo Surabaya dapat disimpulkan sebagai berikut.

1. Pemberdayaan kelompok petani Semanggi Suroboyo dapat meningkatkan gairah dan partisipasi petani dalam demplot budidaya daun Semanggi.

2. Terjadi peningkatan kapasitas produksi daun Semanggi Suroboyo dengan menggunakan biofertilizer sebesar $67 \%$ dalam waktu 1 bulan.

3. Terjadi peningkatan pendapatan petani Semanggi Suroboyo dengan menggunakan biofertilizer sebesar $65 \%$ dalam waktu 1 bulan.

4. Pemberdayaan pembuatan pupuk cair organik/biofertilizer menggunakan limbah industri rumah tangga dapat diaplikasikan ke tanaman Semanggi.

\section{UCAPAN TERIMAKASIH}

Ucapan terimakasih disampaikan kepada Universitas Wijaya Putra Surabaya dan mahasiswa peserta KKN, serta mahasiswa Fakultas Pertanian Universitas Wijaya Putra yang telah memberikan kontribusi dalam pelaksanaan kegiatan PPM. Ucapan terima kasih juga disampaikan kepada CsR Astra dengan tajuk Kampung Berseri Astra yang bersama-sama Universitas Wijaya Putra berkolaborasi dalam program Pengabdian Masyarakat kampung Semanggi Suroboyo.

\section{REFERENSI}

Bisnissurabaya.com.,2019, Mengunjungi Kampung Semanggi di Sememi Surabaya, http://bisnissurabaya.com/2019/08/29/mengunjungikampung-semanggi-di-sememi-surabaya/

CA Tresyanto, 2016, Strategi Pemasaran Untuk Menarik Minat Masyarakat Pada Menu Tradisional Semanggi-Surabaya, BIP's JURNAL BISNIS PERSPEKTIF, 2016 - jurnal.ukdc.ac.id

Gita. G, 2019, Icip-icip Semanggi, Pecel Khas Surabaya yang Punya Khasiat (beritabaik.id) https://www.beritabaik.id/read?editorialSlug=kuline r\&slug=1551076782016-icip-icip-semanggi-pecelkhas-surabaya-yang-punya-khasiat

Kurniasari, F, Ganesh Gunansyah, 2019, Semanggi Suroboyo Desa Kendung BenowoSurabaya Sebagai Sumber Belajar Berbasis Etnopedagogi di Sekolah Dasar, JPGSD. Volume 07 Nomor 03 Tahun 2019, 3061 - 3070

Sugijo, Tjitrawardani , 1998 Meningkatkan potensi event "Semanggi Suroboyo" sebagai alternatif untuk meningkatkan jumlah kunjungan wisatawan di Jawa Timur. Diploma thesis, Petra Christian University 